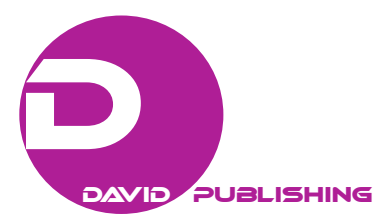

\title{
Online Shopping: What Factors Determine Consumers to Buy?*
}

\author{
Tety Elida, Wahyu Rahardjo, Ari Raharjo, Edi Sukirman \\ Gunadarma University, Kota Depok, Indonesia
}

\begin{abstract}
This study analyzed factors influencing consumers in the process of making a decision in online shopping. The findings could inspire suggestions for online marketers in developing either media or infrastructures accordingly. The variables in the study involved product information, price, service, transaction safety, environment, age, gender, educational background, and income rate as independent variables, while the process of purchasing decision served as a dependent variable. Primary data were gathered in 10 locations within Jabodetabek areas involving 270 respondents which were analyzed using multiple regression analysis. The study revealed that price, information product, and service as significant variables influencing consumers in online shopping. Service became the most important factor for marketers to be considered as it emerged as the most dominant variable influencing the process of making a decision in online shopping.
\end{abstract}

Keywords: consumer behavior, digital marketing, online shopping, web experience

\section{Introduction}

The transformation of conventional into online approaches occurred in various aspects of life since the Internet was first invented (Englis, Solomon, \& Danskin, 2005). The changes pushed mankind to adjust ways of life according to technology advancement. Internet technology has even affected retail trade as numerous online shops emerge and accommodate producers in marketing products and serve consumers in shopping activities. There have also been many SMEs utilizing online shops to expand their markets (Ueasangkomsate, 2015).

E-commerce is very potential in Indonesia (Kemkominfo, 2015). Yet this high transaction opportunity has still been dominated by foreign companies. In response, the government has been working on efforts to increase the performance of local companies and SMEs. One of which is through expanding the market of the national products into e-commerce.

The trend of online shopping is presumably elevated by young generation as the millennial generation that is up to date with technology (Lim, Osman, Salahuddin, Romle, \& Abdullah, 2016). The dynamic, fashionable, and emotional characteristics of this generation lead to online shopping preference. Possessing characteristics of having established careers and better income, the previous generation identified as $\mathrm{Y}$ generation is likely to

\footnotetext{
* Acknowledgement: Thanks to Kemenristekdikti who has funded this research in 2017. This paper had been presented at the 5th Gadjah Mada International Conference on Economics and Business 2017.

Tety Elida, Dr., Faculty of Economics, Gunadarma University, Kota Depok, Indonesia.

Wahyu Rahardjo, Dr., Faculty of Psychology, Gunadarma University, Kota Depok, Indonesia.

Ari Raharjo, Magister Management, Faculty of Economics, Gunadarma University, Kota Depok, Indonesia.

Edi Sukirman, Dr., Faculty of Computer Science and Technology Information, Gunadarma University, Kota Depok, Indonesia.

Correspondence concerning this article should be addressed to Tety Elida, Faculty of Economics, Gunadarma University, Kota Depok, Indonesia. Email: tety@staff.gunadarma.ac.id.
} 
indulge in online shopping as well (Loureiro \& Breazeale, 2016). The dynamic trend of online shopping brings forward the idea that the process of the consumer purchasing decision is interesting to study, particularly in the context of e-commerce.

In e-commerce, the consumers act as both the purchasers and web-based technology users (Cho \& Park, 2001; $\mathrm{Wu}, 2013)$. Thus, how consumers utilized technology as a media to fulfill their needs is important to study. The utilization of technological media in business should serve a two-way-communication, in which a webpage does not only view information but also provide interactive features for consumers (Forsythe, Liu, Shannon, \& Gardner, 2006), including solving consumer anxiety towards the product after purchasing it (Hong \& Yi, 2012). Another necessary issue to be considered is consumer risks in an online transaction, such as the safety of the online transaction system (Taylor \& Strutton, 2010).

Companies utilizing e-commerce must understand their consumers' demands and behaviors (Lee, 2002). Meanwhile, many researchers did not find fundamental differences in consumers' behaviors between conventional and online shopping (Lee, 2002; Liebermann \& Stashevsky, 2002; McKnight, Choudhury, \& Kacmar, 2002; Suh \& Han, 2002; Liang \& Lai, 2002).

Consumer behavior in purchasing items using technology is interesting to be studied. The study of an e-commerce website is a dynamic study as technology has been developing rapidly in every sector. Purchasing decision is the key variable in the series of consumer behavioral model (Kottler \& Keller, 2016). Several issues related to consumer purchasing behaviors are how an individual comes into purchasing decision, probable social factors influencing it, and the probability of demographic factors influencing it (Kottler \& Keller, 2012). This study aimed at analyzing factors influencing the process of making a decision in online shopping which could enlighten marketers in developing supportive media and infrastructures.

\section{Literature Review}

At first, purchasing decision is stereotyped in a simple concept, which is how consumers perceive product price, and whether the price meets product quality (Kottler \& Keller, 2012). Several findings implied that price had been one of influencing factors in purchasing decision in online shopping (Scarpi, Pizzi, \& Visentin, 2014; Bauboniene \& Guleviciute, 2015). In advance, purchasing decision provides more scopes to study as it deals with interesting relations and not only limited to sole perception of the product price. Cheung, Zhu, Kwong, Chan, and Limayem (2003) categorized factors influencing consumers' decisions in online shopping into two, namely: uncontrollable factors, such as consumer characteristics and environmental influences; and controllable factors, such as product or service, media, and intermediary characteristics.

\section{Marketers' Uncontrollable Factors}

Several studies showed that demographic, social, economic, cultural and personal, and psychological factors highly influenced consumer behaviors and decisions. Yet, they were factors uncontrollable by marketers (Harrell \& Frazier, 1999; Czinkota \& Kotabe; 2001; Solomon \& Stuart, 2003). Other studies also showed that characteristics, such as age, gender, educational background, and income rate influence online purchasing behaviors. Kotler (2005) stated that factors influencing purchasing behaviors were the financial state, age, family, social status, and job.

Another marketers' uncontrollable factor is an environment. The social environment is whole social interactions happened between consumers and surrounding parties or people (Sumarwan, 2003). Meanwhile, 
Schiffman and Kanuk (2000) stated that the socio-cultural environment was comprised of the family, informal source, non-commercial source, social class, culture, and sub-culture. The significance of socio-cultural aspects influenced the purchasing behaviors of consumers (Kotler, 2005).

Online shopping behavior either via a web or certain social media demanded personal social knowledge before getting involved in the purchasing process (Chen, Lu, \& Wang, 2017). This social knowledge is transferred to an individual from the social environment, such as friends, other consumers' reviews, discussions in Internet forums, and so on (Hajli, 2015).

\section{Marketers' Controllable Factors}

Marketers' controllable factors are related to marketing mix concepts. The marketing mix is demanded manageable marketing tactical strategies applied by a company to ensure the desired responds in the target market. Marketing mix consists of every effort a company could work on to influence product demands. It is comprised of four group variables called 4P: product, price, place, and promotion (Kotler, 2005). In the context of service marketing, Booms and Bitner (1981) suggested a 7P approach, which added 3P: people, process, and physical evidence. People are defined as all parties, directly and indirectly, involved in the consumption service. The process is defined as procedures, mechanism, or service activity scheme. Physical evidence is defined as an environment in which service takes place.

In online marketing, the concept of people is not compulsory as the purchasing process is carried out using information technology. Place and physical evidence relate to the characteristics of marketing media. Price is a crucial point ineffective marketing strategy to attract consumers purchasing the products (Huang \& Sarigollu, 2012). Hiransomboon (2012) considered price promotion as a crucial matter as consumers consider it the most before purchasing a product.

Purchasing online differs from conventional way as information should be included as detail as possible to let consumers know well the products they buy. Product information becomes important to protect consumer candidates from unwanted risks. The consumer candidates commonly gather information to trust a product (Wang \& Chang, 2013). Findings showed that accurate information could influence consumer attitude (Petty, Cacioppo, \& Schumann, 1983) and decreased perception of risks towards a product (Kopalle \& Lehmann, 2006).

The essence of online marketing is the website. This must equip security which can be considered as ensuring the consumer data confidentiality and transaction safety. Online shopping security demands a trustworthy web system and features that consumers consider their data kept safe. Assurance, safety, and security in online transaction psychologically built trust which then determines the possibility of purchase (Hong \& Cha, 2013). The unavailability of security feature can trigger worries which possibly cancel out purchasing decision (Grabner-Kräuter \& Kaluscha, 2003; Contantine, 2004).

In reference to the discussion above, factors influencing the process of purchasing decision in online shopping were price, product, service, and transaction safety which served as marketers' controllable variables. Environment, age, gender, educational background, and income rate served as marketers' uncontrollable variables (see Figure 1).

Null hypotheses which could be inferred from this study was that there had not been any influences on the decision in online shopping due to the environment, age, gender, educational background, income rate, product, price, service, and transaction safety. 


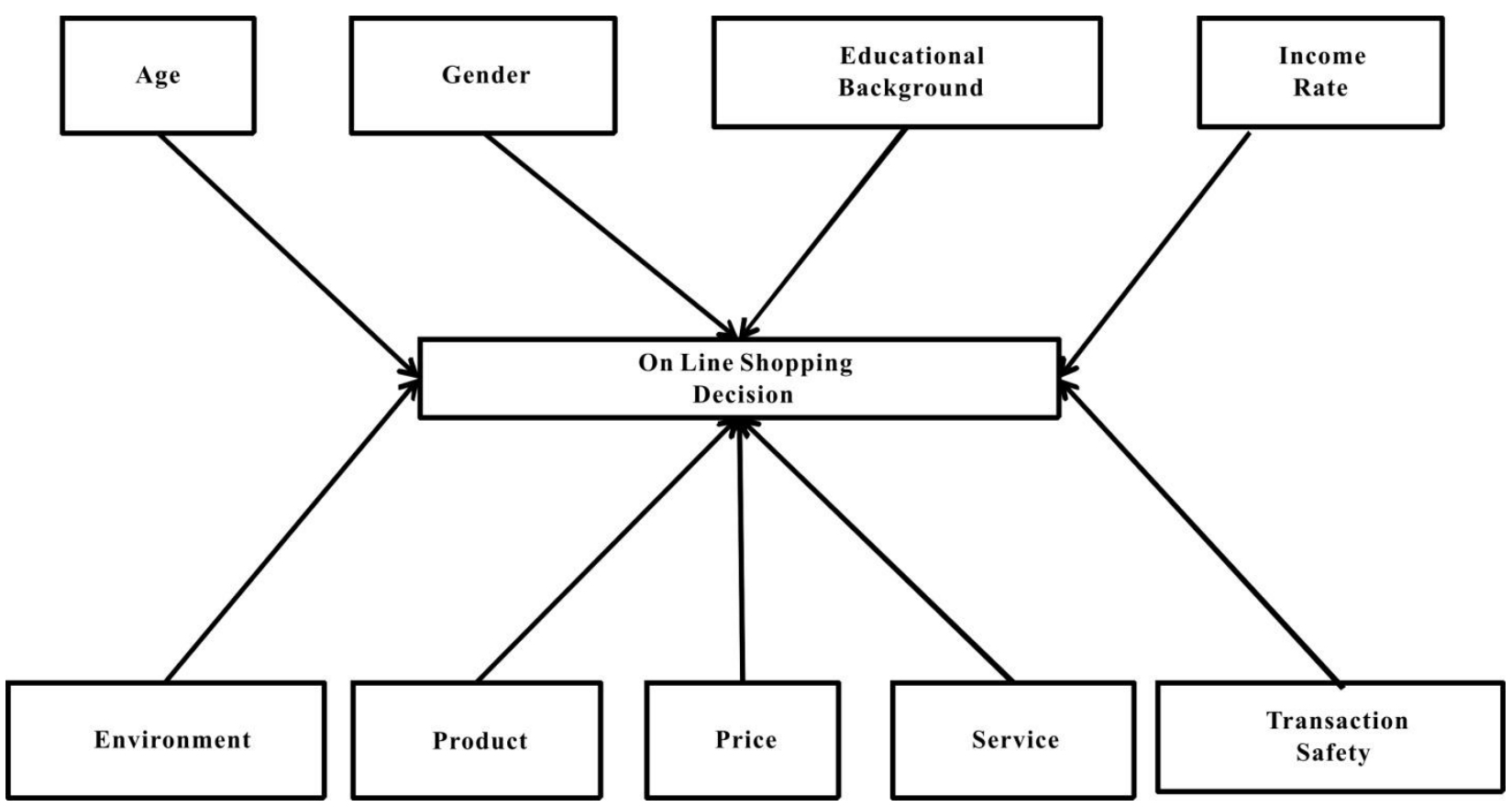

Figure 1. Research model.

\section{Method, Data, and Analysis}

\section{Method}

Respondents of this study were consumers having experiences in shopping online (at least once) through a certain website or social media with age ranged from 18 to 45 years old. The range of age was determined in consideration with the approximate optimal productive and consumptive age. The data were gathered in 10 locations in Jabodetabek from 270 respondents using questionnaires.

Model of the study is shown in Figure 1. Age, gender, educational background, and income rate were observable independent variables. Age is the age of a person expressed in years (numeric). Gender is the nominal data where score 0 is male and scores 1 is female. Educational backgrounds are measured by the level of education, from basic education (Score 1), junior high school (Score 2), high school (Score 3), diploma (Score 4), and college (Score 5). Income rate shows the income level of a person who is given a score of 1 to 5 , where the lowest score of income is less than three million rupiah and the highest income above 15 million rupiahs.

Environment, product, price, service, and transaction safety were unobservable independent variables. The process of making a decision as dependent variable served as unobservable variable had been measured using schemes stated by Kotler (2005), namely problem identification, searching, trust building, evaluation of alternatives, choice, and post-purchase behavior. Each of these unobserved variables is measured using five items adopting 1 to 5 Likert scale. Score 1 indicated most negative respond of being "strongly disagree" and Score 5 indicated most positive respond of being "strongly agree". Several sample items used to measure unobserved variables were in Table 1.

Considering that the dependent variable was measured by six schemes in which each scheme was measured by five items, and then it meets the criteria variable with the interval scale. Therefore, the research model was analyzed using multiple regressions, while gender is nominal, treated as a dummy variable. 
Table 1

Measurement of Unobserved Variables

\begin{tabular}{lll}
\hline Unobserved variables & Sample item & Reliability \\
\hline \multirow{2}{*}{ Environment } & I shop online based on friends' recommendations. & 0.765 \\
& I shop online based on buyers' testimonies. & 0.802 \\
Product & I find detail product information. & 0.808 \\
I can find testimonies of a product I wanted to purchase. & I shop online due to affordable prices generally offered. \\
Price & Online products are relatively cheaper. & 0.769 \\
Service & I favor online shopping due to easy delivery service. & 0.854 \\
Transaction safety & I can chat online whenever having doubts over a product. \\
& I believe that the online transaction is safe. & \\
& I believe in the security system in the online shop I visit. \\
I know products I need. & I always try finding out products I need using web. \\
The process of purchasing & I always ask if the products I need provide a long guarantee period. \\
decision & I compare with other online shops offering similar products I need. & 0.769 \\
& I purchase products online at a cheapest price I can find. \\
& I post positive testimonies of experiences in purchasing products online. & \\
\hline
\end{tabular}

\section{Respondent Description}

The majority of respondents in this study were female (70.1\%) having age ranged from 16 to 35 years old. The majority of respondents' educational backgrounds were Senior high school and $66 \%$ of respondents earned less than three million Rupiah per month. Three most frequently accessed sites were Lazada, Tokopedia, and Bukalapak with the average of the online transaction of one to five times within the last six months. Beside web, respondents also used Instagram for online shopping.

Fashion dominated the types of products purchased by respondents and electronic stuff was next in rank. Almost all purchased products were intended for personal use, not reselling. Most preferred payment method was ATM (70\%), $16.7 \%$ respondents preferred cash on delivery and $9.1 \%$ preferred credit card, the rest paid their products in retail shop appointed as payment agent or using PayPal.

\section{Regression Analysis}

Partial influence of environment, age, gender, educational background, income rate, product price, service, and transaction safety towards the process of making a decision in online shopping is shown in Table 2 .

Multiple regression analysis was used using $\alpha=0.05$, thus the variables considered significant in influencing the process of making a decision in online shopping were regression coefficient with a value under 0.005. In accordance with Table 2, the product, price, and service significantly influenced the process of making a decision in online shopping. Meanwhile, the other six variables had not contributed significant influences.

The value of sig. in Anava test scoring 0.000 (see Table 3) showed resistance towards the zero hypothesis stated previously in the section of the method of the study. It could be inferred that the overall nine variables influenced the process of making a decision in online shopping. The level of influence of the nine variables towards the process of making a decision in online shopping was $22 \%$, as shown in the value of Adjusted $\mathrm{R}$ square in Table 4. 
Table 2

Coefficients of the Regression Equation

\begin{tabular}{lll}
\hline \multirow{2}{*}{ Model } & Standardized coefficients & Sig. \\
\cline { 2 - 3 } & Beta & \\
\hline Environment & 0.092 & 0.065 \\
Age & 0.082 & 0.192 \\
Gender & 0.009 & 0.872 \\
Educational background & -0.079 & 0.224 \\
Income rate & -0.063 & 0.351 \\
Product & 0.221 & 0.001 \\
Price & 0.067 & 0.025 \\
Service & 0.292 & 0.000 \\
Transaction safety & 0.037 & 0.569 \\
\hline
\end{tabular}

Table 3

\begin{tabular}{llllll} 
Anava & \multicolumn{5}{l}{} \\
\hline Model & Sum of squares & DF & Mean square & F & Sig. \\
\hline Regression & 168.898 & 9 & 18.766 & 9.487 & $0.000^{\mathrm{a}}$ \\
Residual & 514.358 & 260 & 1.978 & & \\
Total & 683.185 & 269 & & & \\
\hline
\end{tabular}

Table 4

Determinant Coefficient

\begin{tabular}{lllll}
\hline Model & $\mathrm{R}$ & $\mathrm{R}$ square & Adjusted R square & Std. error of the estimate \\
\hline 1 & $0.497^{\mathrm{a}}$ & 0.247 & 0.221 & 1.460 \\
\hline
\end{tabular}

The findings of Harrell and Frazier (1999), Czinkota and Kotabe (2001), Solomon and Stuart (2003), and Kotler (2005) stated that age contributed influence in making a decision in online shopping, yet this study found it in contrary. This study also denied that demography became the factor that influenced the process of making a decision in online shopping. These contradictory findings might be resulted due to the majority of respondents being in a relatively similar age range. In a relatively similar age, respondents have a relatively equal emotional quotient. Thus, there had not been significant influence towards the process of making a decision in online shopping. Educational background and income rate were also not variables influencing the process of making a decision in online shopping despite the fact that it contradicted with Lee (2002) that stated consumers with higher income preferred online shopping.

Product serves as a variable influencing purchasing decision. This finding agrees with Wang and Chang (2013). Considering how little communication process in online shopping is though information is compulsory. It comes not only from the marketers but also other consumers through testimonies shown on webpage. This signifies the importance of clear and detail information to ensure consumers and omit doubts.

In concern with consumer data of income less than three million Rupiah in a month, it was reasonable if price became a significant consideration in purchasing a product. This finding had been in line with Bauboniene and Guleviciute (2015) that stated price as a factor influencing the process of making a decision in online shopping. Cheaper prices offered compared to conventional stores' had been taken into consideration by the respondents. In addition, no transportation cost was spent to get the product. 
Service became the most determining factor in the process of making a decision in online shopping which was indicated by the highest beta score compared to the other variables. This had been in line with Chung-Hoon Park and Young-Gul Kim (2003) and Bauboniene and Guleviciute (2015) that stated service quality affected online purchase behavior. Speed and ease in the transaction had been one of the significant factors in service quality to ensure satisfying online interaction.

Moreover, the environment had also been a necessary factor in the process of making a decision in online shopping despite its marginal statistical score in this study (see Table 2). Environment variable in this study took into account how friends and information trend contributed to the process of making a decision in online shopping. In the range of age starting from 16-25 years old, in which a person enters an early mature stage, the influence of the environment remained quite high.

Another finding denying the previous ones was transaction safety, in which it did not contribute significant influence in the process of making a decision in online shopping. Transaction safety generally referred to methods of payment, in the assurance that the visited e-commerce website had been equipped with adequate security system. Chung-Hoon Park and Young-Gul Kim (2003), Alhaiou, Irani, and Ali (2009), Mobarakabadi, H., Karami, Maleki Far, \& Yarkarami (2013), and Mittal, (2013) stated web security influenced behavior in making a decision in online shopping. These different findings are likely to happen seeing respondent age range which is categorized in emotional psychological characteristics where risks are ignored. This group is likely to be more consumptive as most of the products purchased were fashion.

\section{Conclusion}

Product, price, and service quality became factors influencing the process of making a decision in online shopping. The detail and clear information on the product minimize risk for consumers. Thus, it omits doubt in purchasing decision. On the other hand, pricing strategy became important as consumers could compare prices with other competitors in online shopping. Discount and free delivery became a way to make a price became more attractive. Another important issue is to sustain service quality. Online communication service with consumers needed to be developed, for instance, providing consumer care which could response consumer inquiries attentively. Responsive communications can also handle consumers' doubts in making a purchasing decision.

\section{Limitation and Suggestion}

The weakness of this study is that the inclusive criteria of early mature respondents are less specific as it cannot contribute deeper conclusions in the findings. Lissitsa and Kol (2016) stated that despite university students as a young group being a great market target, the mature group has more potential in online shopping as they have better purchasing capacity and more vacant time.

\section{References}

Alhaiou, T., Irani, Z., \& Ali, M. (2009). The relationship between eCRM implementation and eLoyalty at different adoption stages of transaction cycle: A conceptual framework and hypothesis. European and Mediterranean Conference on Information Systems, 13-14 July, Izmir, Turkey.

Bauboniene, Z., \& Guleviciute, G. (2015). E-commerce factors influencing consumers "online shopping decision". Social Technologies, 5(1), 74-81.

Bitner, M.J. \& Booms, B.H. (1982). Trends in travel and tourism marketing: The changing structure of distribution channel. Journal of Travel Research, 20(4), 39-44. 
Chen, A., Lu, Y., \& Wang, B. (2017). Costumers' purchase decision-making process in social commerce: A social learning perspective. International Journal of Information Management, 37, 627-638.

Cheung, C. M. K., Zhu, L., Kwong, T., Chan, G. W. W., \& Limayem, M. (2003). "Online consumer behavior: A review and agenda for future research. Proceedings of the 16th Bled E-commerce Conference, 9-11 June, Bled, Slovenia.

Cho, N., \& Park, S. (2001). Development of electronic commerce user-consumer satisfaction index (ECUSI) for Internet shopping. Industrial Management \& Data Systems, 101(8), 400-406.

Constantinides, E. (2004). Influencing the online consumer's behavior: The Web experience. Internet Research, 14(2), 111-126.

Czinkota, M. R., \& Kotabe, M. (2001). Marketing management (2nd ed.). Cincinnati, OH: South-Western College Publishing.

Englis, B. G., Solomon, M. R., \& Danskin, P. (2005). Web-based consumer research. In C. P. Haugtvedt, K. A. Machleit, and R.F. Yalch (Eds.), Online consumer psychology: Understanding and influencing consumer behavior in the virtual world (pp. 491-509). New Jersey: Lawrence Erlbaum.

Forsythe, S., Liu, C., Shannon, D., \& Gardner, L. C. (2006). Development of a scale to measure the perceived benefits and risks of online shopping. Journal of Interactive Marketing, 20, 55-75.

Grabner-Kräuter, S., \& Kaluscha, E. A. (2003). Empirical research in online trust: A review and critical assessment. International Journal of Human-Computer Studies, 58(6), 783-812.

Hajli, N. (2015). Social commerce constructs and consumer's intention to buy. International Journal of Information Management, 35, 183-191.

Harrell, G. D., \& Frazier, G. L. (1999). Marketing, connecting with customers. Englewood Cliffs, NJ: Prentice-Hall.

Hiransomboon, K. (2012). Marketing mix affecting accommodation service buying decisions of backpacker tourist traveling at Inner Rattanakosin Island in Bangkok, Thailand. Procedia Economics and Finance, 3, 276-283.

Hong, I. B., \& Cha, H. S. (2013). The mediating role of consumer trust in an online merchant in predicting purchase intention. International Journal of Information Management, 33(6), 927-939.

Hong, Z., \& Yi, L. (2012). Research on the influence of perceived risk in consumer online purchasing decision. Physics Procedia, 24(B), 1304-1310.

Huang, R., \& Sarigollu, E. (2012). How brand awareness relates to market outcome, brand equity, and the marketing mix. Journal of Business Research, 65, 92-99.

Kemkominfo. (2015). Road Map E-Commerce untuk memudahkan Pelaku E-Commerce. Url: https://kominfo.go.id/index.php/content/detail/5842/Road+Map+E-Commerce+untuk+Memudahkan+Pelaku+E-Commerce/0 /berita_satker

Kopalle, P. K., \& Lehmann, D. R. (2006). Setting quality expectations when entering a market: What should the promise be? Marketing Science, 25(1), 8-90.

Kotler, P. (2005). Manajemen Pemasaran, alih bahasa Benyamin Molan. Jakarta, PT: Indeks Kelompok Gramedia.

Kotler, P., \& Keller, K. L. (2016). A framework for marketing management (6th ed.). Essex: Pearson.

Kottler, P., \& Keller, K. L. (2012). Marketing management. New Jersey: Pearson Education, Inc.

Lee, P. M. (2002). Behavioral model of online purchasers in e-commerce environment. Electronic Commerce Research, 2, 75-85.

Liang, T. P., \& Lai, H. J. (2002). Effect of store design on consumer purchases: An empirical study of online bookstores. Information \& Management, 39, 431-444.

Liebermann, Y., \& Stashevsky, S. (2002). Perceived risks as barriers to Internet and e-commerce usage. Qualitative Market Research, 5(2), 291-300.

Lim, Y. J., Osman, A., Salahuddin, S. N., Romle, A. R., \& Abdullah, S. (2016). Factors influencing online shopping behavior: The mediating role of purchase intention. Procedia Economics and Finance, 35, 401-410.

Lissitsa, S., \& Kol, I. (2016). Generation X vs. generation Y: A decade of online shopping. Journal of Retailing and Consumer Services, 31, 304-312.

Loureiro, S. M. C., \& Breazeale, M. (2016). Pressing the buy button: Generation Y's online clothing shopping orientation and its impact on purchase. Clothing and Textiles Research Journal, 34(3), 163-178.

McKnight, D. H., Choudhury, V., \& Kacmar, C. (2002). The impact of initial consumer trust on intentions to transact with a Web site: a trust-building model. The Journal of Strategic Information Systems, 11(3-4), 297-323.

Mittal, A. (2013). E-commerce: It's impact on consumer behavior. Global Journal of Manage-ment and Business Studies, 3(2), 131-138.

Mobarakabadi, H., Karami, M., Maleki Far, S., \& Yarkarami, K. (2013). Influence of online shopping behavior factors on e-satisfaction of customer. Journal Teknologi, 64(3), 1-7. 
Park, C. H., \& Kim, Y. G. (2003). Identifying key factors affecting consumer purchase behavior in an online shopping context. International Journal of Retail \& Distribution Management, 31(1), 16-29.

Petty, R. E., Cacioppo, J. T., \& Schumann, D. (1983). Central and peripheral routes to advertising effectiveness: The moderating role of involvement. Journal of consumer research, 10(2), 135-146.

Scarpi, D., Pizzi, G., \& Visentin, M. (2014). Shopping for fun or shopping to buy: Is it different online and offline? Journal of Retailing and Consumer Services, 21, 258-267.

Schiffman, L. G., \& Kanuk, L. L. (2000). Customer behavior. Englewood Cliffs, NJ: Prentice Hall.

Solomon, M. R., \& Stuart, E. W. (2003). Marketing, real people, real choices (3rd ed.). Englewood Cliffs, NJ: Prentice-Hall.

Suh, B., \& Han, I. (2002). Effect of trust on customer acceptance of Internet banking. Electronic Commerce Research and Applications, 1(3-4), 247-263.

Sumarwan, U. (2003). Perilaku konsumen: Teori dan penerapannya dalam pemasaran. Jakarta: Ghalia Indonesia.

Taylor, D. G., \& Strutton, D. (2010). Has e-marketing come of age? Modeling historical influences on post-adoption era Internet consumer behaviors. Journal of Business Research, 63(9-10), 950-956.

Ueasangkomsate, P. (2015). Adoption e-commerce for the export market of small and medium enterprises in Thailand. Procedia Social and Behavioral Sciences, 207, 111-120.

Wang, J. C., \& Chang, C. H. (2013). How online social ties and product-related risks influence purchase intentions: A Facebook experiment. Electronic Commerce Research and Applications, 12(5), 337-346.

$\mathrm{Wu}$, I. L. (2013). The antecedents of customer satisfaction and its link to complaint intentions in online shopping: An integration of justice, technology, and trust. International Journal of Information Management, 33(1), 166-176. 